\title{
First Report on the Presence of Phyllachora sp. in Corn Crops at Toluca, Estado de Mexico
}

\author{
Erika Natalia Ríos-Herrera1, Laila Pamela Partida-Martínez ${ }^{2}$, Yisa María Ochoa-Fuentes ${ }^{3 *}$, \\ Ernesto Cerna-Chávez ${ }^{3}$, Francisco Daniel Hernández-Castillo ${ }^{3}$, Alberto Flores-Olivas ${ }^{3}$, \\ Víctor Olalde-Portugal ${ }^{4}$, Raúl Rodríguez-Guerra ${ }^{5}$ \\ ${ }^{1}$ Universidad Autónoma Agraria Antonio Narro, Saltillo, México \\ ${ }^{2}$ Department of Genetic Engineering, CINVESTAV, Irapuato, México \\ ${ }^{3}$ Department of Agricultural Parasitology, Universidad Autónoma Agraria Antonio Narro, Saltillo, México \\ ${ }^{4}$ Department of Biotechnology and Biochemistry, CINVESTAV, Irapuato, México \\ ${ }^{5}$ General Terán, INIFAP, General Terán, Nuevo León, México \\ Email: "yisa8a@yahoo.com
}

Received 14 February 2016; accepted 27 March 2016; published 30 March 2016

Copyright (C) 2016 by authors and Scientific Research Publishing Inc.

This work is licensed under the Creative Commons Attribution International License (CC BY).

http://creativecommons.org/licenses/by/4.0/

c) (i) Open Access

\section{Abstract}

Symptoms of Tar Spot Complex (TSC) in corn appear in the form of black spots surrounded by a chlorotic halo known as fish-eye. The crop with these symptoms was found at San Pablo Autopan, Estado de Mexico. The stromal region of foliar lesions was cut longitudinally, showing perithecia, asci and ascospores typical of Phyllachora maydis. The results were confirmed by PCR-ITS with ITS 1 and ITS4 initiators, cloned by pJET, before being sequenced and compared against NCBI's data base. Phyllachora identity was confirmed. This is the first report where TSC pathogen has been detected under conditions that had not been previously reported, for instance, at 2600 meters above the sea level.

Keywords

Phyllachora maydis, Tar Spot Complex, ITS

\section{Introduction}

Corn ranks first as the cereal with higher yield per hectare, and ranks second in total production, after wheat. ${ }^{*}$ Corresponding author.

How to cite this paper: Ríos-Herrera, E.N., Partida-Martínez, L.P., Ochoa-Fuentes, Y.M., Cerna-Chávez, E., Hernández-Castillo, F.D., Flores-Olivas, A., Olalde-Portugal, V. and Rodríguez-Guerra, R. (2016) First Report on the Presence of Phyllachora sp. in Corn Crops at Toluca, Estado de Mexico. American Journal of Plant Sciences, 7, 733-739. 
Corn has great economic importance worldwide as food source, feed and raw material for industrial products. Corn adapted faster to moderate climate regions, which represent $40 \%$ of the planted surface area, and $60 \%$ of global production. Average yield at moderate climate conditions is significantly higher than in tropical areas. Diversity of the environments, where corn is grown, is greater than for any other crop. However, the growing season of corn cropped in moderate climate regions is longer than in tropical regions, and the relative daily yield of tropical corn is similar to the yields obtained from corn grown in moderate climate. There are few exceptions, in which tropical corn productivity can be compared with the yields obtained in moderate climate; such as corn grown in winter time at tropical regions. Corn grown in tropical environments is subject to the attack of large numbers of pathogens, leading to major economic losses. Paliwal et al. [1] have reported 130 tropical corn diseases, compared to 85 diseases that affect corn grown in moderate climate.

In Mexico, corn's tar spot is considered a major disease in tropical regions due to its impact on yield. Foliar blight can appear in less than eight days, by the coalescence of fungal lesions and toxin production. Some additional factors promoting this disease are: high environmental humidity; 10 to 20 cloudy days in a month; high rates of nitrogen fertilization; two corn crops a year; susceptible genotypes; low luminosity; highly vulnerable host's age and virulence of involved pathogens [2].

Tar spot is caused by the interaction of Phyllachora maydis and Monographella maydis. Furthermore, Coniothyrium phyllachorae, a parasitic microorganism, associated to $P$. maydis, M. maydis and responsible for the "fish-eye" condition linked to the necrotic spot at the center of the lesions has also been found. This complex was first described for Mexican corn in 1904; however it has also been found in Bolivia, Colombia, Costa Rica, Dominican Republic, Guatemala, Panama, Peru, Puerto Rico and Venezuela. Tar spot has also been reported in Ecuador, El Salvador and Haiti [3]. Sampling procedures conducted in 1985 and 1988 in Mexico revealed high incidence and severe corn damage in Jalisco, Michoacan, Hidalgo, Veracruz, Oaxaca and Chiapas, which affected almost 500,000 corn hectares, causing losses of up to 50\%, since the crops were infected before blooming [2]. From 2001 to 2005, about 40\% of the 3100 corn hectares established at Mochitlan Valley, Guerrero were affected by the disease, leading to severe grain yield losses. In 2005, 600 ha were reported totally lost at Tixtla municipality, Guerrero; and by 2007, the disease had already impacted more than 10 municipalities at Guerrero (González et al., 2008). Tar spot causing agents have been detected at Mochitlan Valley and other municipalities of Guerrero state, Mexico, including: Phyllachora maydis Maubl, Monographella maydis Müller \& Samuels and Coniothyrium phyllachorae Maubl, where the disease caused losses of 55.1\% in 81 hybrids and 25 open- pollinated corn cultivars that were sampled [4].

Due to the problems caused by the disease, as well as the presence of the related disease complex in Mexico's subtropical region, the goal was to: report for the first time the presence of tar spot in corn grown at San Pablo Autopan, Toluca, Estado de Mexico, located at more than 2660 meters over the sea level with sub-humid moderate climate and mean annual temperature of $13.7^{\circ} \mathrm{C}$.

\section{Methods and Materials}

\subsection{Plant Material Collection}

50 samples corn leaves from San Pablo Autopan, Estado de Mexico were collected in 2014 fall-winter cop season, at $19^{\circ} 38^{\prime} 9.41^{\prime \prime}$ latitude and $99^{\circ} 42^{\prime} 9.82^{\prime \prime}$ longitude. The samples were collected ten days after the first symptoms appeared, focusing on plants showing dark stromal lesions with smooth and glossy aspect, oval or circular shape and 0.5 to $2.0 \mathrm{~mm}$ in diameter [4] (Figure 1). The leaves were dried and pressed at ambient temperature inside paper bags, to preserve them for testing. The level of damage and severity of fungi associated to TSC were assessed using the scale described by Ceballos and Deutsch, 1992; Hock et al., 1992, shown in the following Table 1.

\subsection{Sample Preparation}

Plant material was washed with 5\% sodium hypochlorite solution and 2 drops of tween per every $100 \mathrm{~mL}$ of water. The material was left standing for 5 minutes before being introduced in a Vortex for one minute. The washing solution was discarded and the washing procedure with hypochlorite solution was repeated three times. The material was rinsed with sterile water before decanting. As a control check, $100 \mu \mathrm{L}$ of the last rinsing water was plated and incubated for 12 to 18 hours. Finally, the tissue was dried in a laminar flow hood, using absorbent sterile paper. 


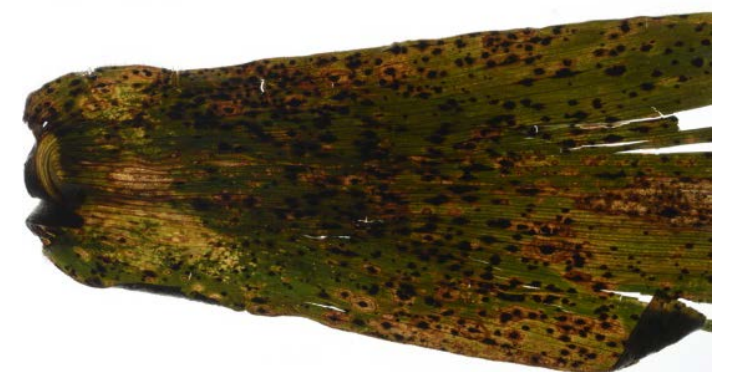

Figure 1. Corn leaf sample with Phyllachora and fish-eye symptoms.

Table 1. Severity scale of tar spot complex in corn (Ceballos and Deutsch, 1992; Hock et al., 1992).

\begin{tabular}{ccc}
\hline Class $^{\dagger}$ & P. maydis & M. maydis \\
\hline 0 & (Number of lesions) & (\% Diseased leaf area) \\
1 & $0-0.9$ & $0-0.9$ \\
2 & $1-100$ & $1.0-8.0$ \\
3 & $101-400$ & $8.1-16.0$ \\
4 & $401-1000$ & $16.1-24$ \\
5 & $1001-2700$ & $24.1-32.0$ \\
\hline
\end{tabular}

${ }^{\dagger}$ Each class is represented in one third of every leaf's length, in the center.

\subsection{Morphological Identification of Phyllachora Genus}

Stromal lesions were cut and scrapped, slicing them at the stereoscopic microscope's slide, before adding one drop of blue catophenol, in order to observe them at the compound microscope under10, 40 and 100× fields.

\subsection{Genomic DNA}

The genomic material for amplification was obtained following DNA's extraction protocol proposed by Wai Kwong Ma [5], using Griffiths et al. [6], Kowalchuk et al. [7], and Schwarzott and Schussler [8] methods. Stromal lesions were scrapped and $100 \mu \mathrm{L}$ of sodium hypochlorite solution at $1 \%(\mathrm{p} / \mathrm{v})$ were added, before stirring inside the Vortex at maximum speed, two times for 30 seconds, followed by centrifugation at $600 \mathrm{rpm} / 3$ min. The liquid was extracted and washed with $100 \mu \mathrm{L}$ of TE buffer $(10 \mathrm{mM}$ Tris-HCl, pH 8.0, $1 \mathrm{mM}$ ethylenediamine-tetra-acetic acid [EDTA]), centrifuging again at $600 \mathrm{rpm} / 3 \mathrm{~min}$ and repeating the washing cycle with sodium hypochlorite solution. TE excess was eliminated. Three crushing/liquid-nitrogen chilling/thawing cycles were performed on the lesions and the material was suspended in $60 \mu \mathrm{L}$ ofTE. An equal volume of phenol was added:chloroform:isoamyl alcohol (24:24:1) before stirring in a Vortex unit for 30 s two times, at maximum speed. The material was centrifuged for $3 \mathrm{~min}$ at $3000 \times \mathrm{g}$. The aqueous phase was extracted and the samples were kept on ice. An equal volume of TE was added to the tube with phenol and the aqueous phase: chloroform: isoamyl alcohol, and the extraction procedure was repeated to increase the yield. In order to eliminate phenol from the aqueous phase, an equal volume of chloroform was added:isoamyl alcohol (24:1) and the tube was placed up-side-down for $10 \mathrm{~s}$, before centrifuging for $3 \mathrm{~min}$ at $3000 \mathrm{xg}$. The aqueous phase was introduced again in a new tube with two volumes of the solution at $30 \%(\mathrm{p} / \mathrm{v})$, polyethylene glycol at 4000 and $1.6 \mathrm{M} \mathrm{NaCl}$. The material was incubated at ambient temperature during two hours to precipitate the DNA. Precipitated DNA was centrifuged at $14,000 \times \mathrm{g}$ for $10 \mathrm{~min}$ to achieve sedimentation. The supernatant was eliminated and the sediments were washed with $100 \mu \mathrm{L}$ ethanol at $-20^{\circ} \mathrm{C}$ al $70 \%(\mathrm{v} / \mathrm{v})$. Ethanol was decanted and the resulting tablet was left to dry for $10 \mathrm{~min}$. Lastly the tablet was suspended in $30 \mu \mathrm{L}$ of distilled, sterile, deionized water. The DNA was quantified and submitted to observation in agarose gel at $1 \%$. 


\subsection{Amplification by ITSs (PCR)}

Genomic DNA was amplified through ITS1 and ITS4 internal transcribed regions between ribosomal genes (rDNA) 18S-5.8S and 5.8S-28S, using oligo pairsITS1 (KIO Fw 5'-TAGAGGAAGTAAAAGTCGTAA-3'), andITS4 (KIO Rv 5'-TCCTCCGCTTWTTGWTWTGC-3'). Each sample contained Buffer 10x $+\operatorname{MgCl}_{2} 2.5 \mu \mathrm{L}$; dNTP's $10 \mathrm{mM} 1 \mu \mathrm{L}$; ITS1 a $10 \mu \mathrm{M}, 1 \mu \mathrm{L}$; ITS4 $10 \mu \mathrm{M}, 1 \mu \mathrm{L}$; Taq polymerase $1 \mathrm{U} 0.2 \mu \mathrm{L}$. Problematic DNA was adjusted at $40 \mathrm{ng} / \mu \mathrm{L}, 1.5 \mu \mathrm{L}$; and $17.8 \mu \mathrm{L}$ of ultra-pure sterile water was added to adjust the final volume at $25 \mu \mathrm{L}$. The conditions of the PCR reaction were: 1 cycle of initial denaturation at $95^{\circ} \mathrm{C}$ for 3 minute; 35 cycles of denaturation at $95^{\circ} \mathrm{C}$ for 15 seconds; 35 cycles of aligning at $48^{\circ} \mathrm{C}$ for 15 seconds; 35 cycles of extension at $72^{\circ} \mathrm{C}$ for 45 seconds and 1 cycle of final extension at $72^{\circ} \mathrm{C}$ for $7 \mathrm{~min}$. The positive check included full DNA of $<$ fungi isolated from strawberry plants (Fragaria $x$ ananassa). The amplification was observed in agarose gel at $1 \%$ through electrophoresis at $60 \mathrm{~V}$, Figure 2.

\subsection{Cloning}

Cloning had four stages: binding, transformation, extraction of plasmid DNA and digestion. In the first stage the PCR product was introduced in a vector like Pjet 1.2. Later, the component cells were transformed through thermal shock. Amplified PCR products were bound to pJET 1.2 vector (Thermo Scientific). In compliance with the manufacturer's instructions, we continued transforming Escherichia coli DH5a competent cells. The transformed cells were plated in LB agar with Carbenicillin $(100 \mathrm{mg} / \mathrm{L})$, using three plating dilutions at 50, 100 and $250 \mu \mathrm{L}$ that were incubated from 13 to $16 \mathrm{~h}$, at $37^{\circ} \mathrm{C}$. After the incubation time, 10 colonies from the plate with large, white isolated colonies were selected at random. An inoculation loop was introduced to those colonies, maintaining a backup sample in a plate with LB and antibiotic; while the colonies were cultured all night, in a tube with LB liquid medium, supplemented by Carbenicillin $(100 \mathrm{mg} / \mathrm{L})$ at $37^{\circ} \mathrm{C}$. Plasmid DNA was extracted from the bacterial growth. Lastly, Plasmid DNA was digested, using Bgl ll enzyme, according to the manufacturer's protocol. The digestion process in agarose gel at 1\% was observed in Figure 3, in order to confirm the presence of positive clones, before sending the material to be sequenced.

\section{Results and Discussions}

\subsection{Morphological Identification}

At San Pablo Autopan in Toluca, Estado de Mexico, 85\% of corn plants presented Tar Spot Complex symptoms, which appeared between 40 and 50 days after planting under field conditions. Table 1 shows sampled plants

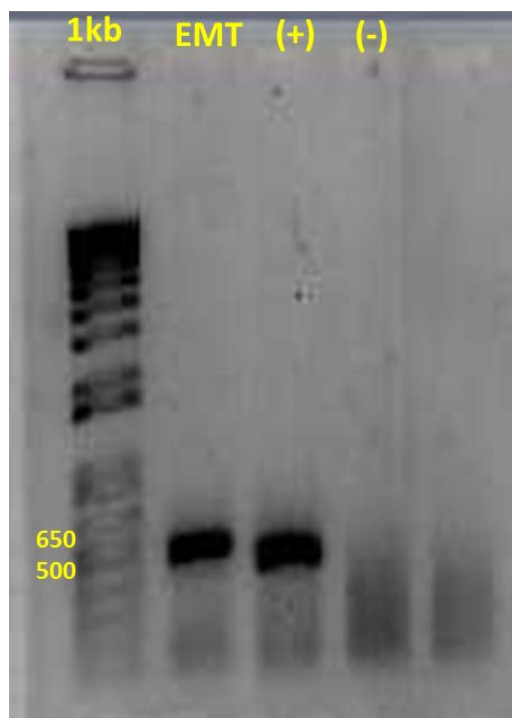

Figure 2. Agarose gel at $1 \%$. The first lane has been marked with the molecular weight, followed by the samples, as well as the positive and negative control checks. 


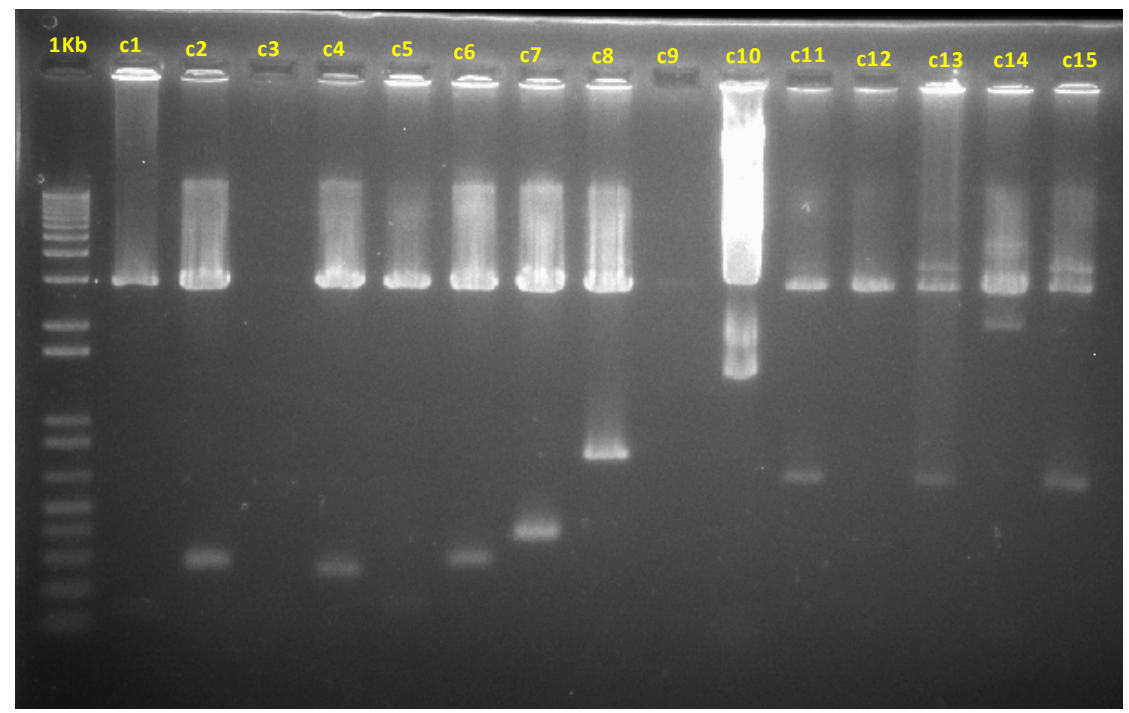

Figure 3. Electrophoresis of agarose gel at $1 \%$ in order to observe the selected colonies and their digestion of plasmid DNA.

that were classified according to the severity scale as Class 2 plants, with $40 \%$ of Foliar Diseased Area (FDA). The plants showed tar spot symptoms caused by Phyllachora maydis in the initial stage, including: dark risen stromal lesions of smooth and glossy aspect, circular or oval shape and 0.5 to $2.0 \mathrm{~mm}$ in diameter, forming striations of up to $10 \mathrm{~mm}$ in length. The most recent study in 2009 reported losses of 55.1\% in hybrid materials; whereas non-official reports have reported $100 \%$ crop losses [4]. Asci are cylindrical, with short elongated pedicels $(180-100 \times 8.10 \mu)$, and eight more-or-less ellipsoidal hyaline ascospores without septa, arranged in mono-serial positions, measuring in average $10.5 \times 6 \mu$ [9], as it's shown in Figure 2. TSC is induced by pathogen Phyllachora maydis Maubl. However, at least other two organisms can be found at TSC lesions: Monographella maydis Muller \& Samuels, and Coniothyrium phyllachorae Maubl. M. maydis is commonly found at the surface of corn leaves, without any apparent reaction of corn plants. M. maydis produces necrotic, elliptical brownish-gray halos around Phyllachora maydis lesions. Currently, the effect of $C$. phyllachorae is not completely known, but it seems to be hyperparasitic of $P$. maydis. However, $C$. phyllachorae is not frequently found in TSC lesions, like the other two organisms [10] (Figure 4).

\subsection{Molecular Identification}

The sequences of EMT (Estado de Mexico, Toluca) sample clones showed the presence of Phyllachorales sp, with access key KM108581.1, proving 87\% identity and confirming the results of morphological identification. Hock et al. [2] established that the optimal conditions for the development of tar spot symptoms are the following: $17^{\circ} \mathrm{C}-22^{\circ} \mathrm{C}$ mean average monthly temperatures, with at least 7 hours of foliar moisture every night and relative humidity > 75\%; or 10 to 20 foggy days a month; or minimum monthly rainfall of $150 \mathrm{~mm}$, and between 1800 to 1900 hours of sunlight a year. In addition, CIMMYT has stated that TSC is commonly found in moderately cool and humid mountain regions, both tropical and subtropical, at 1300 - 2300 meters above the sea level [11]. These were TSC's thriving conditions that had been documented until now. This research work is the first one in recording the presence of fish-eye symptoms, as well as the first report in confirming at morphological and molecular levels the presence of Phyllachora maydis under a different set of conditions; as demonstrated by the samples from San Pablo Autopan, Estado de Mexico, located at 19²1'26"N 99³9'27"O and 2609 meters above the sea level. This climate has been classified as moderate sub-humid, with average annual temperature of $13.7^{\circ} \mathrm{C}$; and mean annual rainfall ranging from 1000 to $12,000 \mathrm{~mm}$.

\section{Conclusion}

The characteristic symptoms of tar spot complex are caused by a consortium of fungi that act together to spread the disease, of which the main role is played. Phyllachora maydis acts mainly in subtropical climates with 


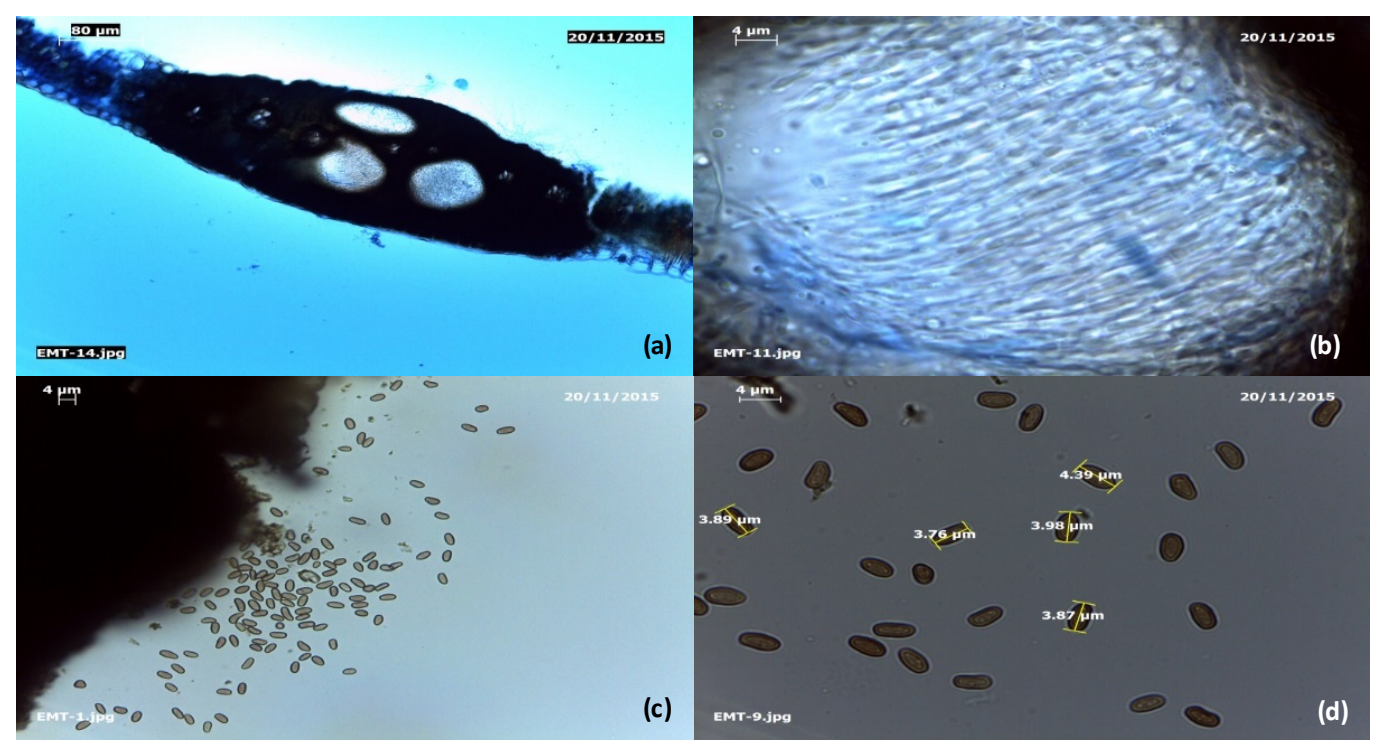

Figure 4. Incisions on TSC lesions. (a) Perithecia; (b) Perithecia with asci and ascospores; (c) Phyllachora maydis asospores; (d) Phyllachora maydis ascospores under 100×.

ideal propagation conditions ranging from temperature range of $17^{\circ} \mathrm{C}-22^{\circ} \mathrm{C}$, to mean $\mathrm{RH}>75 \%$ and $>7 \mathrm{~h}$ of leaf wetness per night [12]. This symptom was identified for the first time in corn samples from San Pablo Autopan, Estado de Mexico. The identity of Phyllachora maydis was confirmed at morphological and molecular levels, stressing the pathogen's adaptation to different conditions compared with the conditions previously reported until now.

\section{Acknowledgements}

The first author is grateful to the Universidad Autónoma Agraría Antonio Narro, the support provided by CONACYT. The authors acknowledge the support provided by the CINVESTAV to carry out this work, and dedicated to the memory of a great friend Juan Antonio Cedillo Martínez.

\section{References}

[1] Paliwal Ripusudan, L., Granados, G., Lafitte, H.R. and Violic, A.D.J.P.M. (2001) El maíz en los trópicos: Mejoramiento y producción. Organización de las Naciones Unidas para la Agricultura y la Alimentación. FAO, Roma.

[2] Hock, J., Kranz, J. and Renfro, B.L. (1989) E1 “complejo mancha de asfalto” de maíz, su distribución geográfica, requisitos ambientales e importancia económica en México. Revista Mexicana de Fitopatología, 7, 129-135.

[3] Hock, J., Dittrich, U., Renfro, B.L. and Kranz, J. (1992) Sequential Development of Pathogens in the Maize Tarspot Disease Complex. Mycopathologia, 117, 157-161. http://dx.doi.org/10.1007/BF00442777

[4] Pereyda, H.J., Hernández, M.J., Sandoval, I.J.S., Aranda, O.S., de León, C. and Gómez, M.N. (2009) Etiología y manejo de la mancha de asfalto (Phyllachoramaydis Maubl.) del maíz en Guerrero, México. Agrociencia, 43, 511-519.

[5] Wai, K.M. (2004) A Polymerase Chain Reaction and Denaturing Gradient Gel Electrophoresis Procedure for Analysis of Arbuscular Mycorrhizal Fungi in Soil. Thesis, University of Saskatchewan, Saskatoon, 30-32.

[6] Griffiths, R.I., Whiteley, A.S., O’Donnell, A.G. and Bailey, M.J. (2000) Rapid Method for Coextraction of DNA and RNA from Natural Environments for Analysis of Ribosomal DNA- and rRNA-Based Microbial Community Composition. Applied and Environmental Microbiology, 66, 5488-5491. http://dx.doi.org/10.1128/AEM.66.12.5488-5491.2000

[7] Kowalchuk, G.A., de Souza, F.A. and van Veen, J.A. (2002) Community Analysis of Arbuscular Mycorrhizal Fungi Associated with Ammophila arenaria in Dutch Coastal Sand Dunes. Molecular Ecology, 11, 571-581. http://dx.doi.org/10.1046/j.0962-1083.2001.01457.x

[8] Schwarzott, D. and Schussler, A. (2001) A Simple and Reliable Method for SSU rRNA Gene DNA Extraction, Amplification, and Cloning from Single AM Fungal Spores. Mycorrhiza, 10, 203-207. http://dx.doi.org/10.1007/PL00009996

[9] Malaguti, G. and Subero, L.J. (1972) La Mancha de Asfalto del Maíz. Agronomía Tropical, 22, 443-445. 
[10] Ceballos, H. and Deutsch, J.A. (1992) Inheritance of Resistance to Tar Spot Complex in Maize. The American Phytopathology Society, 82, 505. http://dx.doi.org/10.1094/Phyto-82-505

[11] CIMMYT (2012) Complejo mancha de asfalto del maíz: Hechos y acciones. http://conservacion.cimmyt.org/index.php/es/component/docman/doc_view/922-tarspot

[12] Hock, J., Kranz, J. and Renfro, B.L. (1995) Studies on the Epidemiology of the Tar Spot Disease Complex of Maize in Mexico. Plant Pathology, 44, 490-502. http://dx.doi.org/10.1111/j.1365-3059.1995.tb01671.x 